\title{
Industry, Heritage, the Media, and the Formation of a British National Cultural Memory
}

\author{
David Sables ${ }^{1,2}$
}

Published online: 4 May 2017

(C) The Author(s) 2017. This article is an open access publication

\begin{abstract}
This paper examines the premise that officially sponsored heritage bodies in England are intrinsically involved in the formation of national memories which fail to reflect the stresses within British society and ignore the value of areas of recent past. As a result, investigation of sections of British history is discouraged and the archeological potential of sites of conflict and confrontation between the mainstream elements of society and those seen as threatening it are being destroyed without the proper archeological investigation. This premise will be examined by looking at the how the history of British industry and a former mining community are presented.
\end{abstract}

Keywords Industry $\cdot$ Political ideology $\cdot$ Heritage $\cdot$ Mining $\cdot$ Media $\cdot$ Great Britain

\section{Introduction}

This paper examines the part played by historians and archeologists in the formation of a national cultural memory and identity by British governments which, in my opinion, fails to reflect many of the stresses within modern British society. It is a memory which underplays the value of significant areas of the nation's heritage and leaves large sections of the recent past being seen as something that is best not talked about and ignores the archaeological potential of sites of confrontation between the establishment and those seen as threatening it.

This paper will discuss how archaeologists and historians need to question how and why they assign values to cultural places, whose cultural heritage and ideology is being displayed and their relevance to the audience. It will examine the implications of political and media pressure on heritage studies and the effects it has had on

David Sables

sables55@hotmail.com

1 University of Wales Trinity Saint David, Lampeter, Ceredigion SA48 7ED, UK

2 The Mill, Mill Street, Lampeter, Ceredigion Wales SA4 87HX, UK 
communities and why these pressures should be recognized and if necessary resisted. The paper will go on to discuss the role played in the formation of National Memory by English Heritage (the UKs government agency tasked with protecting and preserving England's cultural remains (Thurley 2013)) and the National Trust for Places of Historic Interest (or Natural Beauty - although known more commonly as the National Trust, a charitable institution which has statutory powers to buy and preserve what it deems are important historic buildings and places of outstanding beauty). This paper will examine how these arms of the state direct heritage narratives by deciding what is of value and worthy of protection and what will be preserved for future, which is an integral part of a political process of reinventing the National Memory. The paper will also outline how this and the political wish to make heritage economically productive has stimulated the expansion of the heritage sector until it has become an industry in its own right with the constraints this involves. Finally, the paper examines these issues through the lens of how heritage has responded to British deindustrialization and the demise of the British Coal Industry.

\section{A Brief History of Post-War Identity-Building}

The popular idea of what is British and how it came to be, is a narrative that has been made and remade many times in response to the nation's role in the world and changes in contemporary historiographical approaches. These ideas on what Britain is have in turn, influenced the way the British people have thought about themselves and their nation. As Hobsbawn outlined in 1988, history is part of the fund of knowledge or ideology of a nation; it is not what has been preserved in popular memory but as an official selection of narratives. These narratives are popularized by those deemed responsible enough by the state to pass them on to the public, with those in the most powerful positions being given the most authoritative voice (Bailey and Popple 2011). This voice represents the dominant ideology and is omnipresent. Its narrative is reinforced through formal education and repetition in the mainstream media and as such society is taught to value the narrative of the reporter above that of the person who carried out the act.

Often these official ideological narratives involve a forgetting of popular traditions, memories, and meanings in favor of invented tradition in order to achieve a political aim. The kilt and Highland games which figure so prominently in the media and ideology when referring to Scottish identity are examples of this process. These ancient symbols of Scotland are, in truth, a recent invention made popular by English men in the nineteenth century as part of a move to integrate the Scots into British society after the Jacobean revolts; the true garb and traditions of the Scottish people have been left to the studies of academics (Tervor-Roper 1988:2). These fictitious traditions have become legitimized through repetition, formalization, and by the sponsorship of the powerful, and in most cases replace local community memories.

Such traditions may also be used at a more local level to encourage appropriate behavior and to reinforce social order while undermining community ideals which are deemed inappropriate by the state (Little and Shackle 2014:41). Often these invented traditions are allied with approved popular modern pastimes such as football, running, and brass bands with prizes being provide by employers. This is opposed to traditional 
pastimes deemed as inappropriate, such as hare coursing (running down wild hares and rabbits with specially bred dogs), bare fist fighting, and other aggressive sports being discouraged or made illegal. Some traditions still linger on, being practiced covertly despite this in many former mining communities, but as such communities have become diluted and their traditions becoming less prevalent (Bidmead 2015). A good example of the installation of approved traditions was the introduction of the May Queen and Maypole Dancing. These traditionally rural spring activities were introduced into schools and at galas in the planned industrial communities that were developed across Britain in the late nineteenth and early twentieth century, and continued to be performed in schools in these areas well into the 1960s despite representing a way of life that was in stark contrast to the urban lifestyles of those taking part in the celebrations. These rituals were aimed at promoting nostalgic and emotive power of an idealized community and implied continuity of the bonds of loyalty and feudal paternalism born out of a rural idyll which those involved may never have experienced. The use of a rural ritual to reinforce feudal authority within an urbanized industrial-based society is symptomatic of the problems faced by a governmental system that is from a system that, in the main, remains in the control of the descendants of the landed aristocracy (Gove 2015).

This feudal authority and deference is reinforced to the population through education, the media and the building of the idealized national identity which is installed at a young age. Open any children's book on the British Nation published in the first half of the twentieth century and you will find it full of references to the British Empire and its industries. These were the two pillars that were used to portray the country's identity until the 1960s. From the nineteenth century, Britain's role in the industrial revolution and its heavy industries were used as a core around which the British national identity and the class system were constructed (Thompson 1966). The ability to invent, manufacture and sell was portrayed by the state and in the media as being something which distinguished Britain from the rest of the world. The British industrialists were portrayed (and to an extent still are) as benefactors who started the industrial revolution and were introducers of modernity to the Western world. However, as Britain's massproduction industries declined in the face of global competition and the population began to lose its connection with the production process (Hothi 2005), British governments sought to reconstruct the British self-image as a modern technological and scientifically advanced egalitarian nation, and more recently Britain has been promoted as the world's first post-industrial nation; an idea which involves consigning industries to the nation's past.

This is an ongoing process under which British governments have sought to change Britain's self-image for their own ends for centuries; however, the process has become more overt over the last seven decades. In 1945, the newly elected Labour government sought to rid Britain of its unequal society and rigid class system that had changed little from the late Victorian period (Timmins 2001). This inequality had been shown in a stark light in the post-First World War period, which was marked in many areas of Britain by economic depression, high unemployment, hunger marches, poor housing, and decreasing wages, while in the south-east of England and for the wealthy it was a time of economic boom and increased prosperity (Smith 1998). The Second World War brought full employment and political bargaining power to the working people. The socialist parliamentary members of the Wartime Coalition Government and the trade 
unions were determined that, in return for their hard work and sacrifices of the workers that, radical social change would be achieved, that the hardships of the Hungry Thirties would not return and that the fighting men, unlike at the end of World War 1, would return to a country truly "Fit for Heroes". In order to answer this need Britain's war time National Coalition Government asked William Beveridge, a respected economist and Richard Austen Butler the conservative minister for education, to produce reports on possible reforms and improvements to Britain's education and social system. Beveridge's report identified five main areas of concern which he called the "Five Giant Evils" (Timmins 2001 :12). These were Unemployment, Want, Disease, Squalor and Ignorance. Before the introductions of the reforms- the vast majority of children left school at the age of 14 years having been in the same school from the age of five, having almost no chance of proceeding with their education (Balzer 2013). Butler's Education Reforms resulted in a far reaching Act which introduced, amongst other things, a new tripartite education system which for the first time, gave all children free education up to the age of 15 , and the children of the less well off the chance of attending university on merit rather than wealth (Balzer 2013).

The Labour Party under Clement Atlee campaigned in the 1945 election for the full implementation of both the report's recommendations, nationalization of key sectors of the economy and a fundamental change to British society as a reward for the sacrifices of the population during the war. The Conservative Party under Winston Churchill campaigned on loyalty to Churchill as a war leader and for continuity rather than change. The result was a landslide victory for the Labour Party which was elected with a majority of 183 Members of Parliament (Kynaston 2007). The policies of the 1945 Labour government maintained full employment, despite the influx of large numbers of demobilized men from the armed forces into the labor market. The Labour government managed to improve the housing stock, radically changed the countries' education system and introduced what at the time was a revolutionary National Health System (the NHS) (Jargo 2015). The Government was able to introduce these radical changes in part by continuing to portray, into the post-war period, the wartime ideology of Britain as a nation whose people were working together towards a common goal. This idea was reflected in the media and at art events, such as at the Festival of Britain, which sought to transform the way that people saw Britain by popularizing contemporary design and modern buildings (Atkinson 2012), and by coming to terms with living within the vast amount of reconstruction taking place, not only with the urban landscape, but also that which was being undertaken within society.

The size of the election defeat in 1945 led to a Conservatives realization they had misjudged the British electorate's desire for change and as a result, for the 1951 election, they changed their political policies to support many of Labour's policies including Keynesian economics. Keynesian economics were central to Labour's ideas as he advocated state interference in the market economy in order to control the free market's worse excesses and stimulate trade (Keynes 1936). The 1950s Conservative governments that followed Labour continued this theme and sought to foster the idea with the population that they were reaping the rewards for their hard work (Bogdanor 2011). However, they sought to limit the changes that Labour had introduced when in power, whilst acknowledging that if they were to remain in power they had to move towards the left of politics. The similarity in political standpoint this caused between the two main British political parties became known as "Consensus Politics" and lasted for 40 years 
(Kavanagh and Morris 1989). Consensus Politics, the new economic position of Britain's position in the post-war world and the needs of post war reconstruction necessitated a re-evaluation of British self-identity. However, the idea that Labour had sought to portray in the Festival of Britain, that the old-world order had been cast-off in favor of all things modern, was unpalatable to the conservative establishment and despite its enormous popularity it was soon torn down (Rennie 2007).

In post-war Britain, the conservatives and establishment needed a sense of identity which legitimized their holding of power, and as their power was based on historic privilege they required an identity which not only retained the past but elevated it. The inauguration of Queen Elizabeth II in 1953, proved opportune by providing the conservative government of the day a central theme and a figurehead for its new national identity that reflected not only the continuity of the ruling establishment that the monarchy represented but also modernity in the form of a young queen. The Conservative government, which had been elected in 1951 using slogans such as "Britain Strong and Free" and safeguarding "our traditional way of life" (Butler 1999 :54), initiated yet another change to the idea of Britain's national identity. It fostered the idea that the country had cast off the worst aspects of the staid, class-ridden Victorian past while keeping traditional values and embracing modernity, and as such had entered a new glorious Elizabethan period.

This revised portrayal of Britain was reinforced through the use of media and in particular television. The new theming started with the televising of the royal inauguration and media references which linked the new queen to her sixteenth century forbearer and which was then reinforced through popular television series such as The Buccaneer, Sir Francis Drake (Chapman 2015) and the national obsession with jet aircraft and the new buccaneers of the sky, the test pilots (Hamilton-Paterson 2011). It is also in 1950s that British academics studying in the fields of history and archaeology began courting television and the idea of the archaeologist presenter as an expert was introduced. Mortimer Wheeler was the first, and perhaps the most successful, of these using the new media to raise his profile and gain public backing and funding for his work (Wheeler 1974).

The increasing prosperity that marked the 1950s and the development of the welfare state allowed the Conservative government to portray the impression that the British class system had ended with Word War II and that a new kind of consensus politics had replaced it (Black 2004). In reality the political situation was more complex. Throughout the decade the established elites maintained their control of positions in the government and the economy by denationalising the banking system and maintaining the privileged position of private education (Bogdanor 2011). The establishment, however, could not reverse the political changes that Britain undertook in the 1950s such as decolonisation and a declining role as a military and cultural power (White 2013:26). This decade saw the emergence of a British population that had become far more consumerist in its outlook and contained a confident working class with a developing youth culture sector (Kynaston 2013). The political and educational changes also prompted a change in archeological emphasis and approaches as a cohort of antiestablishment academics and playwrights of working and middle class origin, known as "the angry young men" (Williams 2007), made their mark. These people sought to make their fields of interest more realistic by disputing the idea that life in Britain had been was idyllic. One of the changes that took place within 
British archaeological study was the development of industrial archaeology (Palmer and Neverson 1998). This area of archaeology, however concentrated on, and continues to concentrate on, recording the remains of eighteenth and nineteenth century industries. British archeologists and historians struggled with the political and methodological difficulties of recording the remains and history of large and complex industries of the later twentieth century (Stratton and Trinder 2000).

The 1960s saw the idea of the British living in a new Elizabethan golden age come under pressure as exports declined and a growing deficit in trade with the rest of the world developed. In response to this pressure, Harold Wilsons 1964 Labour government put forward a new vision of Britain as a dynamic, scientific, and technologically innovative country (Timmins 2001:214). In this "new Britain" the government fostered the idea that Britain had thrown off its staid persona and become an egalitarian, Hip Britain. This re-born Britain looked to the future rather than the past, and its new symbols belonged to the ordinary people; the best known of these include the Austin Mini automobile, the mini skirt, and the Beatles (Sandbrook 2009). This new British identity persisted into the 1970 s as large, technically challenging and capital intensive projects, which had been initiated in the 1960s (including new towns, the expansion of the university sector, and the world's first supersonic airliner Concord, were completed (Turner 2013).

\section{The Evolving Heritage Sector}

The political changes of the postwar period were mirrored in the study of history and archaeology and developed the germination of what would today be called social inclusion agendas. The heritage sector marked the changes brought about by the idea of popular culture and an egalitarian Britain by developing "History from Below" (Thompson 1966). "History from Below" sought to explore the history of ordinary men and women and the part they played in society rather than the traditional historical studies which focused on the actions of the, mainly male, elites. The most prestigious and well known works to emerge from this "History from Below" sector was the seminal work The Making of the Working Class by the marxist historian E.P. Thompson (1963). Archaeology of this period was marked by similar changes with the development of community archaeology, and processual archaeological theory (Binford 1962). The 1970s saw a continuation of the themes of Britain as an egalitarian, innovative manufacturing society, but as the decade progressed this theme came under increasing criticism by political parties and the media, especially as the economy slowed under pressures produced by the energy crisis, inflation, a series of runs on the country's currency, and a breakdown in consensus politics. The political consensus that had marked the post-war period ended when a right wing Conservative Government led by Margret Thatcher was elected in May 1979 (Bogdanor 2011).

The election of the Thatcher government in 1979 saw the end of large scale state support of British industry and the introduction of monetarist policies. In their first term in office, the Conservative government pursued a twin policy in which it systematically undermined union power and reduced state financial support for industries (Jenkins 2007:55). Throughout this period, and beyond, the amount of money the state allocated to social amenities was also cut as part of the reduction in public spending, 
including funds allocated to museums, historic buildings and monuments (Evans 2013:22). This reduction in funding was reflected in the National Heritage Act 1983, which established the semi-autonomous English Heritage Act, which, rather than extending protection of heritage, was set up for cost effective management and exploitation of commercial potential of historic properties in state ownership and the development of the heritage industry (Hewison 2007).

The changes brought about by the Thatcher government were seen by a large section of society as regressive and deeply destructive, and so in order to promote and legitimise its policies, several high profile media campaigns were undertaken using history as a central theme. The Thatcher government, in this period, produced a negative national identity by contrasting the Britain of the 1970 s with an idealised view of nineteenth century Britain. The message promoted was that Britain had become moribund and the industrious British people were being undermined by the communist trade unionists and lazy people too reliant on the state. One of the most memorable of these historical media campaigns was the "Put the Great back in Britain" election campaign that still lingered in the speeches of David Cameron, the Conservative Prime Minister from 2010 to 2016 (Hennessy and Ahmed 2014). This campaign used the traditional view of British history that was taught in schools and the narratives portrayed in the newly established English Heritage, museums and in the media to reinforce its message that the Conservatives harked back to Victorian Britain and its supposed values of selflessness and benefaction (Thatcher 1977). The heritage industry helped embed this idea within society by selectively highlighting areas of heritage to the public which gave a positive view of this period and providing funds to promote the protection and promotion of museums devoted to Victorian industrial history, sites such as Iron Bridge and Beamish (Thomas and Lea 2014:29). While these areas and ideals were being promoted, the less palatable side of Victorian life was being played down and re-evaluated for 1980s consumption (Samuel 1999). The principle aims of these Thatcherite polices and Conservative media campaigns were, of course, to undermine the achievements of the post-war consensus, destroying the policies of social libertarianism and promoting laissez faire economics, where market forces regulated the economy free from government intervention (Vinen 2009:102).

In 1997, the newly elected Labour government (known as New Labour) under Prime Minister Tony Blair began their tenure by emulating "Thatcherite" monetarist policies while attempting to present Britain as a country that was about to be rejuvenated by a new government with fresh ideas. Blair linked himself and his government to "Britpop" (Harris 2004:191) by taking part in photo shoots with, and inviting pop stars to, the Prime Minister's residence, number 10 Downing Street. The phrase "Cool Britannia" was quickly adopted by his spin doctors and promoted in the media, the catch-phrase harking back to Wilson's "Swinging London" (Donnelly 2000:6). This "cool" Britain was to be a new egalitarian place where class played no part and where the "Third Way Politics" would produce social change. This kind of politics moved away from ideologies based on wealth redistribution to an ideology based on equal opportunities for all based on social inclusion and expanding higher education. These new opportunities were to come from a vibrant free market economy based on the service sector; This was just as well as they could not come from Britain's traditional manufacturing base, which had fallen by $50 \%$ under the Thatcher and Major governments, and which was to halve again under New Labour (Department for Business 
Innovation and Skills 2010). As these industries declined and the sites redeveloped, little effort was put into reserving examples of them for future generations. Rather, in the face of reduced government interest in heritage and reduced funding, efforts were concentrated on further conservation and exploring the remains of Victorian industries and promoting established heritage sites (Thurley 2009).

The Conservative and Liberal Coalition government, elected in 2010, shrugged off New Labour's human face of Thatcherism (Jenkins 2007), and under the guise of austerity and prudent economics, reduced the influence of the state within society and the services it provided. In defense of these cuts the government, once again, called for the people of Britain to return to Victorian values and a renewed spirit of civic virtue. Local authorities have responded to cuts in government funding by introducing or increasing entrance charges to museums and closing heritage facilities such as museums and even transferring their heritage responsibilities to charitable trusts (Harris 2014:6). The Government also shed some of its obligations for funding responsibilities by reestablishing the English Heritage organization a charitable trust. On April 1, 2015, English Heritage was split into two parts, with the planning and protection duties retained by the state and the remainder of the organization, which has the responsibility for maintain and managing English Heritage sites, becoming a self-funded charitable organization, which has been in effect privatized (the sites remain in public ownership). A grant will continue to be given to English Heritage to sustain it during the transition period but the new charity is expected to break even by 2023 (Steel 2014). The testing point of this new system will come when the government funding ends and the cost of the repairs of less popular proprieties and sites have to be paid for. Already the organization's outreach programs have been axed and many sites have had their opening times restricted to weekends in the summer months in response to budget cuts and low visitor numbers (Kendall 2012:6). The Conservative Government elected in 2015 has continued with the same policy of reducing government expenditure and implementing the changes to English Heritage. The government has, by retaining ownership of the sites, placed the responsibility for the maintenance and presentation of the sites into the private sector. The removal of government funding from a substantial amount of heritage could free the sector from political interference. However, heritage is a subjective idea that is both personal and shared, and is open to state, media and commercial manipulation (J.Apals pers. comm.), and those working within the heritage sector will be ever more constrained by which narratives they can portray because of where the finances come from (Kendall 2016).

Archaeologists are controlled by developer funding which involves negotiating with both developer and government officials to achieve the desired outcomes and the amount of archaeological investigation allowed. While those in the public sector those applying for funding have to tailor their project in order to achieve the funder's specified aims. All of these factors act as a form of self-censorship and favors those who employ specialists to formulate bids or those who have already achieved funding and are therefore a known quantity. This is a system that favors the status quo and the established and increases the power of the government to decide which history is portrayed. The result is that the gulf between what those working in heritage think, and the narrative they actually produce for public consumption, is becoming ever wider, as the actions of those working within the heritage sector are constrained by the need to achieve public funding or employment in the increasingly competitive privatized sector. 
As a result, the egalitarian histories, and "History from Below" (Samuel 2012), which seemed so relevant a few years ago, have all but disappeared and class inequality is now a problem that cannot be talked about (Sayer 2005:224).

In its place British heritage displays are used to emphasize innovation and class cooperation rather than class opposition and stagnation. For example, the part played by British scientists and technicians in the development of computers is celebrated, while by contrast, the decline of other once-innovative British manufacturing and industries, are portrayed, not as something which should be mourned as many of its former workers feel (Turner 2000), but instead as an inevitable part of a smooth, upward transition from a class-ridden Victorian society to an egalitarian Britain. In truth, however, this on-going process is far more violent and contentious. Heritage has become a place where class is something that is discussed in academic terms and used in discussions on theory while not used in the majority of narratives for public consumption. Its use is subdued; and while class mentioned on displays of egalitarian hunter gatherers or the development of inequality in social structures in the Bronze Age, but there is little evidence of it being included in public discussions on later periods or events such as the dissolution of the monasteries in England and Wales which led directly to the formation of the British "Poor Laws" (Brundage 2001), an event which still effects British society today. Instead, the remains of abbeys are marketed as places of peacefulness and meditation.

It is not the case that workers within heritage are being told to "display this and dig that site" as was the case in the former Soviet-dominated European states (J. Apals pers. comm.). Rather it is a reflection of the neo-liberal values of successive UK governments from the 1970s and their practice of denying the achievements of the post-war interventionist governments of Britain and its nationalized industries. Nor does this mean that the heritage expert's voice is passive or neutral in this agenda, as in fact, they are the driver of the process. They provide the authoritative voice in the media portrayal of heritage in newspapers, on radio and in television programs which play such an influential part in how the past is perceived today. This is all part of the merchandising of an industry where public popularity legitimizes the government funding it receives. This funding by popularity has led to heritage organizations courting and seeking exposure not only in the newspapers and television but also by setting up Facebook and Twitter accounts in order to appear modern and worthy of the public money they receive. This has driven their interactions with the public to be increasingly removed from physical interaction towards remote electronic sources. This growing closeness of heritage and the media industries can be seen by the appointment of Daniel Snow, the television presenter who is the son of the journalist Peter Snow, as the president of the Council for British Archaeology (Council for British Archaeology 2014). It is not the use of media to make connections with its audience that is the problem, indeed that is something to be encouraged; it is the growing influence that the media has over how and what narratives are portrayed that is the issue.

The neo-liberal agenda and the need to create media friendly, feel good heritage experiences, has left much of Britain's recent industrial history and heritage, in effect, unpresentable in positive terms. For instance, is it logical to provide publicly funded displays on an industry that had just been run down by government policies and was the subject of a prolonged and critical media campaign? Instead the majority of articles, both academic and from the popular media, concerning the former nationalized 
industries such as the British car industry (British Leyland) are negative. Yet British Leyland was no better or, more importantly, worse than many of its European rivals and is looked back by those who owned its products with fondness. It could be argued that the demise of these industries and the events surrounding them are too recent and contentious, and that an impartial view cannot yet be given by academic writers on the positive aspects of these industries. However academic writers understand that there is no such thing as an impartial stance so these reasons fails to explain why so many books take a critical view of the history of these industries. Perhaps the books on the subject, written with titles such as The Slow Death of British Industry: A Sixty Year Suicide 1952-2012 (Comfort 2012) are just a case of British self-flagellation. Alternatively, they could be part of a defense of non-intervention and monetarist polices which were the root cause of the demise of these industries.

The negativity displayed towards Britain's nationalized and manufacturing industries of the middle to the late twentieth century is unlike that towards any other British historic sector or period. For instance, the heritage articles and displays on poverty and widespread child prostitution of the Victorian period are usually counterbalanced by the era's enterprise and innovation (Williams 2007). The Hungry Thirties are mitigated by the development of new industries and the spread of home ownership (Thorpe 1992). When writing these negative portrayals, I wonder if the writers realize just how socially corrosive they are. These negative portrayals of industries have undervalued the heritage of the people who worked within them and has allowed large areas of cities and towns to be cleared and gentrified. There is little thought of providing a place in which to tell the story of the people who formerly lived and worked there, as in the case of the Titanic quarter, Belfast Cardiff's Tiger Bay, and the London docklands development (Gardener 2008). These are just three of a growing number of areas highlighted by activist and archaeologists as places where local heritage has recently been appropriated by other groups (Layton 1994:12). This is a problem that can only be redressed by allowing those still living, who have been written out of history, to create narratives concerning their heritage (Smith 2011:1). In the case of the people who worked in the industrial sector this is unlikely to happen for the reasons highlighted above.

There is also the issue that what is being studied and preserved is heavily weighted in favor of the period between Queen Victoria ascending the throne in 1837 and the outbreak of the First World War in August 1914 (Claughton 2009:101). This is particularly evident by the emphasis that English Heritage has placed on the protection of industrial remains that date between 1750 and 1914, a period which they have identified as when British Industry was innovative and of world importance (English Heritage People's Views 2014). Other examples of this bias towards the Victorian period can be seen in the larger Living History museums of England. Of the three that are dedicated to industrial life, two, Beamish and Ironbridge are almost solely dedicated to the Victorian/Edwardian period and have even imported buildings which have been used to reconstruct streets and towns dating to these periods (Samuel 2012:169). The third, The Black Country Living Museum, has the majority of its displays constructed around those eras, although it does cover other periods. All three museums portray a sanitized version of middle class life with the scenes of poverty, pollution horse dung and slums being omitted.

These, and English Heritages' weighting towards its favored period of the late nineteenth century, are prime examples of heritage ideology becoming part of the 
experience economy (Pine and Gilmore 1998), where one of the goals is to give people a feeling of shared history and belonging (Thomas and Lea 2014:26). While there is no doubt that the Victorian and Edwardian periods were important, they are parts of a bigger narrative, and heritage organizations involved in such undertakings have, through exclusion, categorized the industries that came before and afterwards as being of lesser worth. This valuing of specific areas of heritage has given governments the opportunity to give an ideological presentation; that the moving of Britain's economy from one based on heavy industry to deindustrialization and reliance on service industries is a natural upward progression (Hadjimatheou and Sarantis 1998:527).

This portrayal of deindustrialization as a natural upward progression is open to dispute regarding its accuracy. Other European countries such as Germany and Italy have experienced the same pressures but maintained their core industries. Britain is the exception rather than the rule, with no other western country seeing as swift or deep a decline in industry as Britain (Rowthorn and Coutts 2013). By avoiding interpretations of Britain's twentieth - century industrial and manufacturing history, heritage institutions are taking away the opportunity for people to learn about and understand this period thus being unable to form opinions such as why and how workers' rights developed. If people do not understand or are only given a partial history behind the process of gaining rights and liberties, how can they fully value these rights? If rights are undervalued, then we risk losing them in exchange for insubstantial political promises.

Nationalized industries were part of the mainstay of the economy in the crucial postwar period at a time when Britain dominated the world market for exports, so surely these industries are worthy of presentation to the public. Is the reason that these industries are not prominent in our heritage displays because they have been portrayed as symbols of what was wrong in pre-Thatcherite Britain? Or is it a fear that the public would look at the variety and quality of the goods produced, and say "if things were so bad then how could the country have produced such good quality products?" thereby questioning the ideology behind recent government economic choices and its version of the national identity?

Asking these questions is not a matter of being nostalgic or looking back at the period with rose tinted glasses. It is simply born from a statement that our recent past has shaped the present and we must investigate it, record it and present our findings to the public in a way that gives the facts for the audience to make their own informed decisions. This can be done through presenting alternative narratives by removing to some extent the overwhelming academic certainty and assurance embodied within official presentations. Much of the audience may wish just to be told with certainty "it was like this" (Q. Drew pers. comm.) but heritage should also be about making people question dominant ideology. In order to do this the UK heritage system must decide whether museums and exhibits are places of education or entertainment. If the latter is chosen then passing on historic information will become rationed by cost and insider information, with the real transfer of knowledge taking place at the regional archaeological trusts or at places of education. The present balance appears to be moving in favor of "fun-fair" heritage or what Samuel (2012:169) describes as "Dark Ride Museums". These museums use display artifacts and archaeology to create an experience where the visitor is guided on a journey back through time to a particular period and is informed with unquestioning authority that this is how it was. A good example of this is the Jorvik Viking Center at York, in England. This museum's website 
boasts "as you travel around the Viking Age city of Jorvik aboard our state of the art time capsules you will encounter the old Norse speaking citizens and see inside their houses" (Jorvik 2015). It also uses its website to advertise the Richard III and Henry VIII Experience, Barley Hall and DIG, all of which are archeologically themed visitor experiences in York (Jorvik 2015).

There is a place for such themed centers within the heritage sector and having more people interested in the past and its events is something that we all strive for; however, such sites tend to display history and archaeology in a single dimension, not to be thought provoking but rather to encourage increased visitor revenue through the use of media driven stereotypes. Thus Jorvik, the story of an excavation of a Viking manufacturing center, has a webpage dominated by a picture of a Viking war party; an idea that the excavation at Jorvik once aimed to rebalance with the story of Vikings as traders and artisans (Q. Drew pers. comm). This problem is not only restricted to displays of the distant past. Already displays concerning recent decades are dominated by media driven stereotypes and aimed at creating a heritage experience based on nostalgia, like "The Good Old Days". Nostalgia generates a memory of the past without its trauma and entertainment programs on television are aimed at producing enjoyment so when they are combined in heritage displays they produce sanitized portrayals of the past. I would question how truthful the displays in museums are when, as at the Castle museum in York, the 1960s are portrayed in the form of sound bites based on the Beatles, Mary Quant, and Doctor Who (York Castle 2014). While this display is an excellent work in nostalgia, set within an excellent museum, it lacks depth and gives a false impression of what life in the 1960 s entailed. To the majority of the population today, the portrayal of life on television and film in the 1950s and 1960s, is something to be aspired to, rather than a reflection of real life (Lawler 2000).

Television programs, for the most part (exceptions being Coronation Street and its likes), portray the ideals of the affluent middle class, and were populated by middle-class men and women; for example, The Appleyard's. This drama series was said to portray an average family, but in reality they were an upper-middle-class family from the home counties (Dodd and Dodd 1992). Life was somewhat harsher. Britain in the 1950s and 1960s was a place where people worked six-day weeks, where there was inequality in the political electoral system, and where women had to give up their careers when they got married (McKittrick and McVea 2000:12). These factors are missing from all but a handful of museums such as The People's History Museum in Manchester and the display at Birmingham Museum where instead they tell the life story of ordinary people living around the city. The Manchester displays are unusual as this is a museum that was established to redress the imbalance which normally favors the capitalist system by telling the history of the British working classes, their unions and their struggle for equality (People's History Museum 2015). The Birmingham Museum display is more usual where one section of the museum is dedicated to the manufactoring, industry and the workers of Birmingham., (Birmingham Museum 2015). It tells the story of the ordinary worker in the form of an oral history of their working lives rather than the more usual view of industry which is told through products or the view of the owners. This provides a very different perspective, to that produced at other museums.

This raises the question of how can we be inclusive and oppose the inequality in the present if we deny they existed in our past, and how can we value our rights as subjects without knowing how short a time we have had these rights? We are currently in a time of globalization and class conflict is growing whilst state support within British society is shrinking (Domingo 2014). Like it or not historians and 
archaeologists are part of the process and affected by it. Therefore, surely there is a duty to record these changes and their effects.

There is also a moral duty to not only be aware of the conflict and its effects within the process of change but to also forward alternatives to the dominant ideologies (Marshall 2009) and at least acknowledge them in the narratives produced. In Britain, archaeologists and historians are trained to strive to portray an impartial history that serves as a reminder of how far humanity has progressed. It is, however, equally importantly to show how humanity can regress if we do not remember what has gone before. If the political victors are allowed to continue to erase or rewrite history then pernicious stereotypes will prevail and in the end those who struggled for so long without voices in order to give us a voice will be silenced. For history is not just about those who write it, but about those who lived it and museums should be telling the story of all of us.

The recoding and investigations of alternative pasts have started to be told by a few academics including Schofield (2005), who has looked at the archaeological legacy of the 1995 Brixton Riots and the peace camp at Greenham Common (Schofield 2005:100), and Kiddey (Kiddey and Schofield 2011). who has investigated the archaeology of homeless people (Kiddey and Schofield 2011). However, the people studying this sector are likely to remain a small minority as there appears to be little interest in investigating such areas. For instance, in 2011 online archaeological and history blog sites, such as the CONTEMP-HIST-ARCH (2011) list was full of suggestions on how to record the archaeology of the royal wedding. Conversley when wide-spread riots broke out in London and other cities across the country these blogs fell silent. This silence suggests that archaeologists were either dismissing the events as not being archaeological, or instead something to be discussed and studied at a later time from a safe distance. By being selective on what is worthy of being recorded archaeologically and ignoring events that are controversial and portraying the UK in a negative way, archaeologists are reinforcing the idea that heritage should produce a feel-good factor and neoliberal national identity. It was put to me that recording the aftermath of such events was best left to the appropriate authorities, i.e., the police and fire brigade. The results of official investigations are limited in their scope and so by archaeologists and anthropologists studying events like the riots, we would gain the opportunity to study relatively rare events, such as the dynamics, flow of movement of large groups and materiality of people involved in conflict. There have been studies of such events but these have been undertaken many years after the event (Ludlow Collective 2001).

What could we have learned if a full archaeological survey had been undertaken at the Orgreave coking site, where in 1984, four days of running battles took place between 8000 police and 6000 striking miners? Orgreave is not just a place fixed in Labour and Union history and ideology, as the place where the 1984/85 miners' strike was defeated, but a place where because of its political importance memories and history are still being made (Massey 2005). An examination of Orgreave made shortly after the conflict could have provided historical evidence of what really happened over those four days, which involved infantry and cavalry styled police charges reminiscent of pre-gunpowder warfare. A detailed investigation of the site could have led to a better understanding of the deployment of both the pickets and the police, and possibly shown if the police had really laid hidden with dogs awaiting an unprovoked mounted police charge (Elliot 2004:72). Such an investigation would also have been politically 
relevant as the events that took place on this site still has the power, even after 30 years, to generate calls for public enquiries into the events that took place there (The Telegraph 2015), for the British Government to apologise for lying to Parliament and interference in the independent British law courts (Douglas 2014; Townsend 2014). This, however, is no longer possible as the events of 1984 were not mentioned in the 1994 archaeological desktop evaluation of the site (Latham 1994) prior to its redevelopment scheme. The site was destroyed by mining in the 1990s and the rest of the site has undergone substantial redevelopment, including changing the name of the area, thereby severing the last links on the site with the traumatic events of that year and opposition to the dominant ideology (South Yorkshire Historic Environment Characterisation Project 2006). Ignoring such sites risks sections of society feeling excluded from heritage and undermines one of the driving forces behind modern British archaeology, a driving force which led, in the late twentieth century, to amongst other things, the development of community archaeology, queer theory, and feminist archaeology (Gilchrist 1999), and a yearning to be relevant to our society.

\section{Archaeologist, Theory, and the Yearning to be Politically Relevant in the World of Pervasive Media}

Archeological theory is normally written in academic and exclusive language, yet the writers often then try to explain these complex ideas in plain English using everyday examples. This is the author seeking to make a common connection with his audiences through shared ideas and experiences. Hodder (2012) does this in his book Entangled (Hodder 2012) when he uses the example of being stuck on a plane because of bureaucracy and safety checks, to explain his ideas on dependency relationships (Hodder 2012:89). The commonalities that authors use have longevity and a wide audience, and so tend to mirror issues common in the period when the book was written. Hodder's example is based on the negative impact of an overburdening bureaucracy and excessive health and safety rules that confined him helplessly on a plane. The explicit choice of these subjects is interesting, as being confined on a plane while it is undergoing non-routine, structural safety checks, is extremely unusual and therefore is unlikely to display commonality with his audience; the idea that helplessness in the face of bureaucracy and intrusive health and safety checks, however, are likely to. This is because both of these themes were central in large media campaigns by political parties, both in Britain and in the USA over the last 40 years (Seldon and Collings 2013). Given the context of the example, it is unlikely that Hodder was making a political point, rather he was using the wide spread media surrounding electoral campaigns of political parties in order to gain commonality with his audience. His use of this example however, reinforces the negative portrayal put out by some political parties (in this case those in favor of scaling down government involvement in the economy and the promotion of laissez. faire policies) and shows just how powerful these media presentations are, and how ingrained these political messages have become in our everyday thought process. While most of these theoretical archaeological articles seek to find commonality and political relevance, in doing so, some reinforce the negative ideas of the dominant strata of society, i.e., that regulatory interference is too intrusive and costly 
to business. The counterpoint that these regulations are the result of reports from accidents that caused loss of life and are there to protect the public, is of course, muted.

The example which Hodder used to make communality with his audience is an example of Wylie's (2004) assertion that systematic biases can compromise even the best of us. Such systematic biases are damaging on several levels, but most importantly because they elevate the views and culture of one group while denigrating another. Government policies and the media are integral in this process and are powerful influences on what is studied in archaeology and history. Governments support, by direct funding, the issues they wish highlighted (Roberts 2010). The mainstream media supports governments by promoting and popularizing particular historical views in the press, in TV programs and in advertisements. This, and lack of funding for alternative points of view, in effect, silences the majority of opposing arguments. An awareness of this influence is important but if archaeologists claim to be inclusive, as they do, they must then also resist this influence and give a voice to those whom the dominant strata seek to exclude. Archaeologists often wish to elevate their own views and standing however if they wish to be inclusive then their interpretations must take into account multiple culture approaches and they should be aware that the articles they produce may also be used by the establishment in unintended ways. One such article that has failed to take this into account, and is an example of Wylie's (2004) systematic biases, is "The archaeology of alienation: a late twentieth century British council house" by Buchli and Lucas (2001:145). The authors state that the project was based on the idea of "exploring the theme of alienation from a dual perspective of the material culture of the marginalized and socially disenfranchised person or family in the late $20^{\text {th }}$ century" and "the process of marginalization and alienation that we as archaeologists effect on the people we study" (Buchli and Lucas 2001:158). There can be no doubt that the authors, when writing this paper in 1997, had the good intention of producing a politically relevant, archaeological study which would highlight the plight of people living on deprived housing estates and in particular, problems faced by women within our society. These were prominent issues in the media at that time, which many people hoped that the newly elected Labour government would address. The researchers examined a recently vacated council house using archeological techniques to see if they could identify who had lived in the house and understand something of the former tenant's lifestyle. The study concluded from the archaeological evidence, that the former occupant of the property was a single parent family (a mother and children). The study went on to say that this female was having a sexual relationship with a heroin user and that the strain induced by the male's drug addiction and possible threat of violence was the reason that the family had vacated the property. Parts of this interpretation may be correct such as the age and gender of the occupants and can be supported by the archaeological findings, however, many of its conclusions are conjecture with other interpretations possible. The main problem with this paper is it appears to have set out knowing what it would find and that despite good intentions the researchers have produced a paper which could be used to reinforce the propaganda that stereotypes tenants on council estates by blaming alienation and poverty on the person's poor life choices and character faults. The study of social housing and social exclusion is a complex subject which in the United Kingdom is deeply imbued with political agendas and ideology and therefore any study by those outside the subject area should not be entered lightly for it is open for use by partisan parties. If, as 
the study implicitly suggests, this is a random council house then it is also implicit that the study is a reflection of life on a council estate.

Several questions should be considered when reading the paper by Buchli and Lucas (2001). Firstly, why did the researchers chose a council house in order to study this problem? Many council house tenants could be considered by those on the evergrowing waiting lists for such housing as being the have's rather than the have not's. Given this, perhaps a better place to look at marginalization would have been with the 2090 families (in 2013) living in council-paid bed and breakfasts accommodation (Local Government Ombudsman 2013:3), or as the archaeologist Kiddey (R. Kiddey pers. comm.) has done, amongst the homeless. Another question that should be asked is why this particular house was chosen? By choosing a local authority house to study marginalization and social disenfranchisement, Buchli and Lucas (2001) have accepted the premise that people living on council estates are marginalized and socially disenfranchised, and in coming to this conclusion they have allowed the opportunity for their paper to be used to reinforce the negative media stories of local authority housing and the people who live in them. News items such as those in the right wing The Daily Mail newspaper portray people living in local authority housing as those making a choice to live on benefits, to overbreed and to receive far more in state handouts than the average wage. For example, a typical headline about these families is "stop criticising me or I'll have another baby, says father of 13 who lives in supersize council house while collecting £53k a year" (Mail 2014). The British Television program such as Channel 4's Benefits Street, is a program that follows the lives of unemployed people. Channel 4 has been accused of being biased and selective in the editing of events by those whose lives they follow. Channel 4 has been asked by Labour Members of Parliament to consider the ethics of this trend of demonizing the poor which makes examining poverty a form of entertainment (Davies 2014). Given this trend, if a council estate is an area of marginalized people why not examine a house that has someone living in it? The very fact that one of these sought-after homes had been abandoned by its tenant without notice means that something unusual had occurred and therefore how representative is this house? This work demonstrates just how ingrained negative media portrayals of this section of British society have become. It also shows how archaeologists do not work in an academic vacuum (Shanks 1996:117) and are, like the rest of us, affected by the politics and media of the present and recent past. The paper, rather than highlighting the social injustice suffered by the people in this study, has in fact increased it by reinforcing the right wing political and media stereotypes of people in social housing. These stereotypes are not merely humorous caricatures, such as the cheeky cockney who formed the basis of so much of film and televisions' portrayal of the British lower classes (Timmins and Stuart-Smith 2001) but is part of a process of transferring blame for poverty from the state to the individual (Jones 2011), and governmental responsibility for the provision of social housing to the private and charity sector (Walker 2001). The negative media stereotypes which Buchli and Lucas (2001) have reinforced imply that all people who live on council estates are single mothers, drugusing scroungers and people who have never had, and have no intention of, getting a job. Although large local authority housing estates can seem intimidating and many estates do suffer from serious problems, the majority of those who live on these estates are normal, honest, hardworking people (J. Grayson pers. comm.). 
At the time of above the study (2001), 19.5\% of British households occupied local authority or social housing (Government United Kingdom 2012). By 2011, this had increased by another $3.5 \%$ households to $23 \%$ (Office for National Statistics 2014a). If one assumes that each household has two adults and one child, then 10.5 million people are alienated from mainstream British society and its values. The Buchli and Lucas (2001) paper raises the question from which society are these people being marginalized and who is doing the disenfranchising? I would argue that these people have their own sense of tradition and heritage which was once spoken of in terms of working class, and that they have been disenfranchised by the loss of their power caused by deindustrialization. They are being alienated by the comfortably affluent sector of society whose ideology heritage elevates. This ideology is reinforced by the British heritage industries' obsession with works of art, castles, and stately homes (Mullins 2007).

These are themes which this paper is aimed at raising and which archeologist discuss in their studies of capitalism (Hamilakis 2007). Being poor or out of work does not mean that people undervalue their culture or identity. It should also be remembered that not so very long ago the heritage that politicians and the media were celebrating included working class ethics and these very same council estates as examples of "Britain Building”, an inclusive caring society (G. Stevenson pers. comm., Murie 1997:438).

The central reason for poverty on these estates is the decline in the industries that had supported them and the swiftness with which this decline happened. In 1960, 38\% of the British work force were employed in manufacturing; by 2011 this number had dropped to $9 \%$, with the majority of these losses taking place in the last 30 years (Office for National Statistics 2014b). The decline has been compounded by lack or failure of government regeneration initiatives, which has left these areas run down, deprived, and underserved, in stark contrast to the Londoncentric focus of investment which sees $£ 2,900$ per person spent on infrastructure in London compared to $£ 5$ per person in the northeast of England (Cox 2011: 4, McDowell 2003). There has been a call for people within these communities to change, retrain, up-skill, and adopt new practices, thereby shedding the negative legacy that surrounds their former occupations. To this end, towns, villages, and estates that were once proud of their industries, now play down this heritage in order to compete for scarce jobs (J. Grayson pers. comm.). This is, in effect, blaming the people for becoming unemployed and devalues their past. This can have a devastating effect on a community, as in the case of the village of Woodlands near Doncaster, South Yorkshire, England.

\section{Woodlands; The Haunted Land}

Woodlands is a village $3 \mathrm{mi}(4.8 \mathrm{~km})$ north of Doncaster and was purpose-built to serve the former Brodsworth coal colliery. Woodlands is situated at the center of the South Yorkshire Coal Field and is typical of many former coal mining communities in the area. Its 4000 houses straddle the busy Great North Road, the highway between London and Scotland. This road forms the village's main street and the shops that line this road are, today, a mixture of betting and charity shops, fast food outlets and convenience stores. The view of the village gained by travelers on this road is of an estate in decline with broken boundary walls, boarded up houses, and overgrown central parks. The impression is that Woodlands is the kind of council estate described in the pages of The Daily Mail, The Sun, and The Express, but delve a little deeper and things are a more complicated and different from the first impression. 
The village of Woodlands was created in open countryside in 1907 to house the miners of Brodsworth Colliery which had been sunk two years before. Brodsworth colliery worked four coal seams from 1905 to 1990, the deepest of these found at a depth of $1841 \mathrm{ft}(561 \mathrm{~m})$. At its peak, the colliery employed 4000 miners making it the deepest and largest colliery in Europe (Fordham 2009). The housing stock that makes up the village today is a mixture of state (council-owned) housing, houses built by the colliery and privately built houses. Woodlands was also originally constructed as a model village. The state and private houses are of a style that can be seen in most parts of the UK today, however many of the houses built by the colliery owners are of a unique design and arguably of national importance. Woodlands was to be an example of how good colliery housing would improve the lot and raise the moral standards of the laboring classes (Fordham 2009). The village was designed by the eminent architect Percey Bond Houfton as a self-contained community in the style of what he saw as an English country village. He designed 16 different styles of houses which surrounded ten separate areas of green parkland, with the whole village surrounded by a stone wall pierced by four gates that were closed at sunset each evening. The colliery provided all the needs of the community by building a church and a cooperative society shop while the morals of the miners were protected by the banning of selling alcohol in the village (Fordham 2009). The housing stock was based on the ideas of Ebenezer Howard (1900) and although on a smaller scale, it was built to a similar standard as the Rowntree model village of Earswick, near York and the Bournville Estate at Birmingham England. Because of its importance as an example of philanthropy, Woodlands was chosen to be part of King George V and Queen Mary's tour of the industrial area of northern England. The King and Queen arrived at the village on June 9,1912 and were guided around a miner's house by its tenant Mr. Hennery Goodlad. While the King and Queen were looking around the house, two explosions at the nearby Cadeby colliery killed 88 men (the toll would have been much higher had not so many men taken the day off work to see the Royals pass through Doncaster). After leaving Woodlands, the King and Queen lunched with Lord Halifax at Hickelton Hall before returning to Lord Fitzwilliam's country home at Wentworth Woodhouse for dinner. The records of the conversation at Wentworth woodhouse contain no mention of the disaster, however the royal couple visited the site of the disaster the next afternoon (Baily 2007).

The homes that the King visited on those two days highlights the inequality that typified Britain in the early twentieth century. Both Lord Halifax and Earl Fitzwilliam owned royalties for coal in the Doncaster area (including Cadeby colliery) (Baily 2007) and received more in duty per ton than the miners earned digging the ton of coal. Wentworth Woodhouse, the Earl of Fitzwilliam's home has the longest frontage of any palace in Europe and is presently the largest privately owned home on the European continent (Wentworth Woodhouse 2016). By contrast, many of the miners living in Woodlands had moved there from Cadeby, the site of the mining disaster and a place that was described as the worst village in England at that time. The poor reputation of Cadeby had been acquired not only due to its deplorable housing stock, but also from the colliery owner's draconian attitude towards its workers. The Company had a reputation for paying low wages, victimising workers who joined a union and had a policy of evicting deceased miner's family within weeks (Baily 2007). Cadeby pit village was as a slum and demolished in the 1960s. 
The mining families of Woodlands had fared better than those in Cadeby as Brodsworth mine was known as a safe pit and was proud of its safety record, with only 103 men killed there in its lifetime and having suffered no major coal mining disasters. The village itself was officially designated worthy of preservation in 2011 because of its special architectural and historic interest by Doncaster Metropolitan Borough Council. Today 26 buildings in the village are scheduled to be listed for protection. However, this status has been put on hold until an Urban Renewal Scheme has been completed. This Urban Renewal Scheme was put on hold due to funding cuts and so the protection offered by designating this as an area for conservation does not currently apply (Doncaster Metropolitan Borough Council 2014). For these reasons, and despite its heritage importance, many of the historic buildings are suffering damage and vandalism and this area has become the most dilapidated part of the village with a general air of being deprived and run down.

In Woodlands, the villagers depended on the mine owners not only for work and housing, but for their education, health and social life. The school was built as part of the model village. However, the miners paid for and employed their own doctor, a scheme that Ernest Bevin said inspired him to set up the British National Health Service (Timmins 2001), until the arrival of the welfare state which took over paying for these buildings and services. The spiritual needs of the village were also taken care of by the colliery as the mineral owners at Brodsworth Hall built the Anglican Church. A chapel (the Wesleyan chapel) and the Roman Catholic church were paid for by the mining congregations (Fordham 2009). Levies on the miners' wages were used to build the Miners Institute and other buildings where the Union and miners could meet. Eventually these buildings became partly subsidized by the Coalfield Industry Social Welfare Organization (CISWO) (2014). The Miners Institute also contained a miners' library which later became the village's public library. Levies from the Brodsworth Miners' wages, and grants from CISWO, also provided facilities and money for the brass band, football and cricket teams and a cycle track that attracted many of the top British cyclists of the 1940s and 1950s (R. Sables pers. comm.). In addition to this, the Miner's Welfare buildings provided places where films were shown, dances and concerts were held, and where the village library and youth club were housed. The miners paid for the buildings while the mine owners donated the site of an old village waste dump and surrounding wasteland, which was converted by the miner's welfare scheme into a village green, with ornamental gardens and a children's park (Fordham 2009). The Miners Welfare also acted as a place where people could meet the National Union of Mineworkers representative or talk to their local Member of Parliament (MP). The political life of the village was also dominated by the colliery as Brodsworth Miners made up the majority on the council, and all but one of the wards' MPs between 1905 and 2005 were former Brodsworth miners (K. Hughes pers. comm.). This link was broken when in 2005 Edward Miliband, the Parliamentary Leader of the Labour Party and Leader of the Opposition until 2015, was imposed on the local Labour constituency by Labour's head office despite vigorous opposition by the local party members (J. Mousey pers. comm.).

In short, village life in Woodlands was almost totally reliant on the colliery, with a strong sense of community and comradery of the miners and their families, and the revenue brought into the village by the mine.

Therefore, the devastation caused by the mine's closure in 1990 should not be underestimated or unexpected. In one stroke, the local council lost the majority of 
its business and local taxes. As businesses closed, miners, and those reliant on them for income, became unemployed or moved to other areas in search of employment. When the mine closed, the local authority housing, which was already financially stretched after being forced into taking over the Doncaster areas National Coal Board housing stock (many of which were in a dilapidated condition), were unable to finance afford improvements or regular maintenance to the housing stock and all unessential housing repairs were put on hold. When the area's finances were further reduced by cuts in government housing funds in order to save money, the bandstand and childre'ns parks were dismantled, flower beds were dug up, central greens were left uncut and the village began its swift decline (J. Mousey pers. comm.).

In 2014, Doncaster (the area under which Woodlands comes for economic reporting) was ranked as the 28th most deprived area of Britain (The Guardian 2014), with an unemployment rate of $11.6 \%$, almost twice that of the national average (Beatty et al. 2012:28). Woodlands is now an employment blackspot within the Doncaster area and a corpse of its former self with boarded up houses and broken down boundary walls. This is in part because work for the Housing Regeneration Project was started and then stopped part way through when funding was further curtailed due to government austerity cuts.

There is a feeling amongst some of the villagers that the state has not only abandoned them but is actively working against them (K. Hughes pers. comm.). The village is today a prime example of Gordon's (2008) idea of a haunted social landscape and how such areas operate. In Woodlands, the buildings themselves shout out their heritage with foot high letters that say Miners Welfare, Miner's Library and Deputies Club, underlining the reason that Woodlands' existence disappeared when the miners lost their battle and the colliery was closed. As one former Brodsworth Miner told me, in the pubs and clubs where men once gathered and talked of cutting coal, they now talk of the good old days and how much coal lays to waste, unworked below, and of a murdered industry (K. Bidmead pers. comm.). Woodlands is a community which still talks about itself as being a pit village, a place where deep-seated resentments of the loss of a way of living haunts its present life.

This resentment resurfaced on the death of Baroness Thatcher, who is portrayed as defeating the National Union of Mineworkers and whom many miners blame for destroying the British Coal Industry. On her death, spontaneous celebrations and street parties broke out in this community and in other former mining villages across Britain (The Telegraph 2013).

However, as well as resentment, there is also a feeling of a community fighting back to regain its sense of worth. A community newspaper has been started and the village Mayday celebrations, which died out in the 1950s, have recently been revived, as has the village Best Garden competition. It is a resurgence that is coming from within the community itself and is based on its own cultural identity and history (R. Woodhead pers. comm.), as it is from a community that values its own industrial heritage. Heritage in general is a valuable resource, which those involved in the regeneration of such deprived areas can, and have, used to increase community confidence and pride, and to attract funding resources in to the area (Barker 2014). However, this interest by the villagers is not being responded to by official bodies, who appear to be withdrawing from the area in response to government austerity cuts. 
That there is an interest in industrial heritage, such as the coal industry, within British society is undeniable, as was demonstrated in an English Heritage survey undertaken in 2014. In Yorkshire, the county in which Woodlands is situated, over $91 \%$ of those interviewed thought it was as important to preserve industrial remains as any other piece of heritage. Perhaps more importantly, $46 \%$ of the people surveyed in this county said they would be interested in getting involved in an industrial heritage project. A mere 3\% thought that such sites should be demolished (English Heritage People's Views 2014). Taking these results into account, plus the fact that Woodlands is an important example of a model village, and it is the site of Europe's deepest and largest coal mine, one would expect that heritage would play a large part in any regeneration plans for the area. In European countries, mining heritage has been used as a basis for regeneration projects (such as Wales, Ireland, and France) which have used mining remains to re-build community identities based on mining heritage (L. Barker pers. comm.). However, in England the opposite is true.

As with many former mining sites in Britain, following the 1984/85 miners' strike, the Brodsworth colliery buildings and mines headgear have been torn down and the enormous shafts filled in. The spoil tips have been reworked and the whole site has been grassed over and planted with trees, turning it into a pleasant 99 ha community woodland while the colliery stone quarries have been filled with water and turned into wetlands (Forestry Commission 2014). The only physical reminders of the mine are three small concrete blocks, approximately $3 \mathrm{ft}(0.9 \mathrm{~m})$ high, which mark each of the sites of the filled-in shafts, and half of a winding wheel which had guided the ropes that lowered the cages full of men into the mine. The shaft marker blocks are set off the path within an area of segregated and fenced off woodland surrounded by signs which say private property and warn of prosecution should anyone try to reach the site of the former works. The winding wheel was removed from the mine site and re-erected on the grounds of a local church.

The only other heritage display in the village was set up by the villagers themselves in a small side room of the local library. One full wall of the room had been covered by the Brodsworth branch of the National Union of Mineworkers banner which is emblazoned with the lodge motto, "Not Thyself but the Cause." Two other walls had been covered with children's drawings, family photographs, and letter-size papers with hand-written personal histories. These letters told of family histories, events, the kind of jobs they and their forebears undertook at the mine, and of course the 1984 Miners' Strike. The fourth wall was blank apart from a few flyers relating to retraining, outreach educational courses, and drug and crime helplines. This miners display was removed and thrown away when the library was closed in January 2015 when the library staff were made redundant and the library was handed over to volunteers the same month as part of the local Government funding cutbacks. The banner was sent to the National Union of Mineworkers Headquarters, Barnsley for storage. Displays such as these are often dismissed and delegitimised as simply nostalgia for the past, however heritage is not merely something that is initiated from above and passed down. It is a community's sense of self and identity and people should be allowed every effort to take ownership of their heritage, otherwise it becomes depersonalised and taken away from them to be retold by the agents of the state as part of the narrative of the dominant ideology (Samuel 2012:291). The small room in the library was alive with real and relevant history, the history that mattered to this 
community and produced by the people of the village for the people of the village. The displays in this room were the formal juncture between what Chambers (2006) described as private heritage and public heritage, and can be seen as a reassertion of community identity and a narrative, and a rejection of how the village is perceived by outsiders. Above all it showed just how important heritage and a sense of place is to the people of this village. When the display was taken down it was one more step in the removal of the industrial history of this area.

Today there are no deep coal mines left in Britain and the last generation of miners are now dying away. As a result, the disconnection with "King Coal" has grown to such an extent that many children from mining villages today cannot identify a piece of coal when shown it (R. Woodhead pers. comm.). This disconnection will only increase because, although this industry has dominated the area for over two hundred years, it is almost entirely ignored in official presentations of Doncaster's history. A tour of museums in the Doncaster area has revealed that there are only two coal-based displays: a recreation of a Victorian miner's kitchen in Cusworth Hall Museum of South Yorkshire Life and a small display in Doncaster Museum which shows how coal was formed and mined up until 1967 (both of these museums have been restricted to opening three days a week). It appears that, at least in terms of heritage, the soot and coal stains have been cleansed from Doncaster's history.

Instead of learning about the British coal industry, the history of their families and the industry that supported them, the schoolchildren of Woodlands and surrounding mining villages are taken on visits to local "Notable Country Houses." Here they are told of the life of the former owners and their servants, and given the chance of dressing up and taking part in role play based on the life of Victorian scullery maids and butlers (Moffat 2005). One of the large houses around which the children of the community are shown is Brodsworth Hall. Brodsworth Hall is just under a mile to the west of Woodlands and was the home to the former owner of the land upon which the colliery was sunk. The owners of Brodsworth Hall leased the mine site out in return for a payment per ton of coal raised and retained the mineral rights until they were taken over by the state. In 1990, the dilapidated Brodsworth Hall and grounds were donated to English Heritage by its owner Mrs. Williams, on the provision that they then purchased the entire contents of the building for $£ 3.36$ million (Constantine and Allfrey 1999:116). This was the same year that Brodsworth Colliery was closed and its workforce made redundant (Fordham 2009). Further money was then spent on the house and its gardens to restore them back to their former glory. The Hall's decorations, wallpaper, and contents were conserved and restored to reflect the material history of the family since the house was constructed. This was a technically difficult undertaking which pushed the boundaries of conservation (Babington and Hughes 1992) and by 1995 (the latest date that figures are available for), when the house was opened to the public, a total of $£ 6.66$ million had been spent on the site (M. Wilkins pers. comm.). English Heritage's presentation of Brodsworth Hall is aimed at creating a feeling of continuity, cultural refinement, and leadership. It emphasises the contribution that the family had made to the nation both in times of peace and war (Moffat 2005). On both the web site and in the displays within the house a great deal of emphasis is placed on medals won and official public positions held by members of the family. The house is also part of the Yorkshire Country House Partnership, which includes Castle Howard (site of filming for Brides Head Revisited), Nostell Priory (site of filming of "The Forsyte 
Saga"), and Harewood House (site of filming of Death Comes to Pemberley). As such, it is part of the branding of "The Country House" by English Heritage, The National Trust and the media as the quintessence of Englishness and a treasure to be saved for the people (Samuel 2012:58).

English Heritage encourages local schools to visit the Hall, providing teacher information packs and suggestions of how the trip can be used to educational advantage. Themes covered in the pack include "what homes were like a long time ago," "the work of the servants," "decoration and design," and "conservation" (Moffat 2005:7). The visits and displays at Brodsworth and other such country houses are aimed at producing a feeling of inclusiveness, continuity, and shared belonging within its audience. The assumption that underlies visiting such heritage sites with these forms of participation is that people (especially those from deprived backgrounds) can be socially and culturally "improved" by being exposed to the history of the upper classes (Smith 2006:30). The re-evaluated message promoted by English Heritage and the National Trust, that these large houses belong, and have always belonged, to the people and that those that owned houses such as Brodsworth Hall were merely custodians of a shared history, is whimsical. These displays are far from a portrayal of a shared history for they exclude any exploration of heritage that are in opposition to it, and support instead the class-based elitist ideologies which they were originally built to represent (Smith 2008:162).

One of the roles of the great house was to promote laissez faire politics and they are an ideology made real in bricks and mortar (Laslett 1965:171). They are a choreographed display of wealth that excludes the darker side of life in these buildings and the hardships that were endured by others in order to fund opulent lifestyles and the building of magnificent statements of power. Today they are now the displays of the victors and an example of how heritage is used to justify past inequality while influencing the future. The homes of the rich and powerful have had a rebranding, so rather than being symbols of separation, elitism and power they are now marketed and portrayed as being symbols of refinement, connoisseurship, and civility. We are told that we should regarded them not only as the jewel in the nation's heritage crown but as an iconic signifier of national identity (Dresser and Hann 2013:20). The narratives within these buildings are designed to glamorize the lives of aristocrats and gentry and to give an idealized portrayal of their owners as being benevolent and paternal, wishing only good for the nation and its people.

This is not a history that is reflected in the surveys carried out by the Victorian social campaigners Seebohm Rowntree and Charles Booth (Rowntree and Bradshaw 2000; Simey 1980). They recorded this era as one of great wealth and power for the few and great poverty for the masses, where for many working families the difference between ruin and starvation, and survival was a penny a week. It is doubtful that the miners at Brodsworth colliery thought well of the coal owners living at Brodsworth Hall and other stately homes in the area, after their fellow union members at nearby Silkstone Colliery were evicted from their homes by the local land and mine owner Lord Londonderry for going on strike in 1891, victimized them in retaliation for joining a union (Baily 2007:72). Nor would the 3000 men, women and children at the nearby Cadeby Colliery, think well of their mine owner who evicted them in the depth of winter for going on strike in 1903 (Bayiles 2004:299). Cadeby Colliery also had a policy that if a miner was killed underground his wages were 
stopped from the time of the accident. This was a fairly widespread practice however this firm took it a step further by ensuring that the workers family were evicted as soon as possible (Bayiles 2004:299). Would these miners agree with English Heritages' positive stereotyping of the elites' role in society while their story remains untold and hidden? This positive portrayal of the British aristocracy is reinforced by the active association of the heritage sites with British television dramas such as Downton Abbey, The Forsythe Saga, and Selfridges, all of which are part of generating a national memory and identity. As Hobsbawn and Ranger (1988:9) suggests, they are fictions which legitimize a legacy of inequality. As Michael Gove, former Minister of Education, wrote: "for some of us Victorian costume dramas are not merely an agreeable way to spend an evening, rather they are enactments of our inner fantasies" (Stanley 2011:6).

The elevation by the film, television, and heritage industries, of the owners of houses such as Brodsworth Hall to selfless paragons of virtue is the other side of the process of demonizing people living on council estates. It is a case of heritage being used to place the history of the few above that of the many. In this case the heritage of one family living at Brodsworth Hall has been deemed worthy of preserving, while the history of Brodsworth Colliery, Woodlands village and the thousands who lived and worked there have been landscaped out of existence.

The fortunes of Brodsworth Hall are a stark mirror image to that of Woodlands. The first 90 years of the twentieth century saw the village prosper and the Brodsworth Hall decay, then the last 30 years has witnessed a reverse in these fortunes. Now the village of Woodlands has been starved of funding while the multi millionaire's stately home has been able to draw on a seemingly bottomless purse. The presentation of the people from Woodlands and the owners of the Hall have also under gone this switch in fortunes. In the 1950s the occupants of country houses were seen as symbols of moribund out-datedness (Samuel 2012:58), but by 2014 it is the former miners of Woodlands who are described as the negative legacy of the past. Today the homes of the working classes are being presented as dirty and unkempt and their inhabitants as illiterate, anti-social, and violent, things which our society has to be protected from (Jones 2011:25).

\section{The English Coal Industry Strike; What Strikes?}

The projection of these neo-liberal ideas on national identity and the formation of a shared sanitised history can be seen in heritage displays concerning the coal industry. The coal industry is perhaps the most significant of British industries and was, in 1913, both Britain's largest employer (with over five million people working as miners), and the world's largest exporter of coal. The miners were at the forefront of the struggle for workers' rights and in doing so suffered notable victories and defeats. The most notable of struggles were the 1912, 1926, and 1984 miners' strikes, all of which are seen as defining moments in British industrial relations and pivotal points in British history (Milne 2004:ix).

The coal industry has also seen the most dramatic decline of any British industry over the last 35 years. In 1980, the coal industry was an expanding, government-owned 
enterprise employing 242,000 miners who produced over 112 million tons of coal a year from 219 deep mines. By 2014, this industry had changed beyond recognition and is now privately owned, employing under 4000 people who produced around four million tons in 2013 from three deep mines, two of which shut in 2015 leaving under a thousand men employed in British coal mines (Department of Energy 2014; UK Coal 2014). This decline is not a reflection of the amount of coal that is not being burnt anymore, as Britain consumed 61 million tons of coal in 2012, 43 million tons of which was imported, $89 \%$ of which was used to produce $43 \%$ of Britain"s electricity (United Kingdom Government 2012). Nor is the decline a reflection of the modernity of the industry, which was once one of the most technically innovative and advanced in the world (in the late twentieth century), something which is a cornerstone of many museum displays (M.Faul pers. comm.).

The National Mining Museum for England was established in 1988 at the site of the eighteenth century Caphouse Colliery at Overton near Wakefield. Despite having poor transport links, this museum attracts over 100,000 visitors per year (the same footfall as Brodsworth Hall) and has won several awards for its displays (M. Faul pers. comm.). The museum has a library which holds a large number of social archives including collections of miner's oral histories, the National Union of Mineworkers banners and photographs. Visitor attractions include underground tours and static displays of mining machinery. The museum also includes a living history aspect with actors portraying the life of miners in the Victorian period with added gravitas due to the underground guides being former miners. In 2014, the museum ran a special exhibition called "Courage, Camaraderie and Community" which explored mining community solidarity through art and poetry (National Coal Mining Museum for England 2014).

Although the museum covers the entire history of coal mining in England, its main emphasis and the overall feeling is one of the celebration of Britain's achievements in mining technology, indeed, from the displays one would think that the mining industry is still alive and thriving in the UK today. The museum also houses displays on health and safety and aspects of life of miners and their families. 2014-15 was the 30th anniversary of the year-long 1984/85 miners' strike and so it would be expected that a number of the museum displays would be dedicated to the events of that year. The 1984/85 miners' strike was the longest and most violent strike in British industrial history and is now seen as a pivotal point in post war British political history (Douglass 2010). It was a dispute which saw over 180,000 miners and their families (over 500,000 people) come together in civil disobedience, not over wages, but over Margret Thatcher's Conservative government's economic policies (Thatcher 1993) in defense of their jobs. The miners stayed on strike in the face of the full force of the establishment for over a year (Samuel 1986). It was a strike that polarized the politics of the country and effectively destroyed trade union power in Britain (Winterton and Winterton 1989). Therefore, one would expect that it would be well represented in the museum displays. However, the displays on the strike have been confined to half of a $2 \mathrm{~m} \times 1 \mathrm{~m}$ cabinet tucked away next to a side exit, and a separate wall mounted television that played looped news reports of the violence on the picket line. The only other references to any industrial action are some photographs and memorabilia concerning the 1.7 million miners who went on strike in 1926. This display occupies the other half of the same small cabinet as the 1984 strike. By stark contrast an art 
display dedicated to the role of the Bevin Boys took up a large room (the 48,000 men who were conscripted by the wartime Minister of P ower Ernest Bevin to work in British coal mines during World War II [Hickman 2008]). This blunt lack of information about industrial disputes was also noticeable on the museum web site, where the 1984/85 miners' strike is mentioned only in the context of a passing daily tweet.

The almost total lack of information on industrial strife at a mining museum seems extraordinary as this is an industry whose history is defined by its strikes, one of which led directly to the downfall of the conservative government in 1974 (Winterton and Winterton 1989). The result of these displays, or rather lack of them, is that history is being rewritten. The national strikes of 1926, 1974, and 1984 and a diffusion of the politics of a nationally divisive dispute that still dominates the public's perception of the industry have been omitted from the displays in order to produce a pleasurable museum experience. The way the former coal industry is portrayed is understandable, as it shows the management of the industry working in cooperation with the workforce and that its closure was part of a move towards greener energy. To do otherwise would be to question the rationale and conduct of the UK Government and the Coal Board during the 1984/85 strike, these being in essence that the government had the right to abandon the agreements on consultation rights made with miners under the plan for coal and decide that if a mine did not make a significant profit then it would be closed no matter what the social consequences. To remind the public of counter arguments and questioning, the National Coal Board's, (or rather the government's version of events) would include reminding visitors that the government and Coal Board had expended over $£ 8$ billion ( $£ 18$ billion at today’s prices) fighting a political dispute over closing mines (MacGregor 1987:365). This would be unthinkable for a government funded museum, and even if the politics of management was in favor of such a display, to show the Coal Authority in a negative light would risk it withdrawing its sponsorship. This would be devastating to the museum and the private coal companies who donated the site and majority of the material within the museum as the Coal Authority represents the now defunct National Coal Board.

To remember the Miners' Strike (1984/85) would raise questions with the audience, such as why is the government talking of an energy crisis and the lights going out if we still have 1/5th of the world's coal reserves? Or, if we burnt 61 million tons of coal in 2012 producing Britain"s electricity why not produce the coal ourselves? (United Kingdom Government 2012), or were the striking miners right? Why are miners who want to work being made redundant? It would also remind the public of the ongoing questions of police infringement on civil liberties during the strike (Millar and Walker 1984:36) and why the freedom offered by laissez faire politics and a neo-liberal agenda requires evermore intrusive government policies.

These are divisive questions that heritage is discouraged from invoking and policies now dictate that heritage themes produce the feelings of inclusion and belonging. To this end, the National Mining Museum is confident in presenting the wrongs of child labor in coal mines in the 1840 s because the government is shown as progressive and enlightened, and mining is portrayed as something no man should be made to do. These presentations are encouraged because they are positive and in this case the state is portrayed as being paternal, working for the best interests of the people, and controlling the worst excesses of capitalism. It is impossible, however, for the museum to portray the positive aspects of the 1926 and 1984 strikes for they show the government 
oppressing a substantial portion of the population. Qualities such as belief in a cause, community spirit and solidarity enabled the mining communities of the 1926 and 1984 strikes to withstand the full force of the state and media onslaughts for months (Milne 2004). Interestingly the 1984/85 miner's strike figure prominently as a central theme in the displays of National Coal Mining Museums in Scotland and Wales, whose devolved governments have a conservative minority as opposed to the Westminster Governments which has a Conservative majority. (Big Pit 2015; National Coal Mining Museum for Scotland 2015).

Despite the themes of their public exhibits not including the anniversary of the strike, the National Mining Museum does hold information on the disputes in their comprehensive archive of documents, including oral histories of people who took part in the strikes. However, these can only be accessed by appointment. In this way the Museum has segregated information from its audience, with one presentation for the general public and another for those who are willing to spend time and effort exploring what the museum has to offer behind the scenes. While the museum encourages visitors to the archive, and it would be nice to think that everyone would be interested, all archives require an understanding of how they work and most of which are not really user friendly. For this reason, archives are the realm of the academic or journalist, both of which reach specific audiences and which have an interest in supporting the status quo (Shaw 2012:5). This informal restriction of information is to the benefit of the state, after all it is not in the interest of the state to fund political themes that conflict with its ideological agenda. Perhaps that is why successful venues like Caphouse Colliery and The Peoples History Museum in Manchester (2015) (the only other large museum in the Britain that offers Working Class Histories), have had their funding cut more drastically than other similar venues and are now in danger of closure despite attracting large numbers of visitors (M. Faul pers. comm., People's History Museum 2015).

\section{Pine}

While the memories of the miner's strike are still fresh and too controversial to be effectively reworked and used in the present process of national identity building, the creation of nostalgia around the events in the media has begun. After a long absence, mining-related phrases have begun to reappear in newscasts, and pictures of miners are being used to sell various groceries, i.e., a packet of cheese which has been matured in a coal mine for extra strength or the television advert for bread which includes a boy running between the lines of police and pickets in the 1984 strike. Miners are now being portrayed as loyal followers who were betrayed by their leader rather than as they were in the 1980s, as mobs set on undermining democracy (MacGregor 1987).

The selective ignoring of certain historic events, such as the miners strikes, while at the same time commoditising other areas of heritage, is disturbing as the process removes people and issues from the narratives that are being presented to the public. Thus when people ask what British industrial history is they are presented with positive narratives based around Victorian progress such as the development of steam engines and the introduction of legislation to prevent children working down coal mines. It is a portrayal of industries that is frozen in time and ignores the fact that these industries have changed radically since the nineteenth century, that they still exist, and that they still play a large role in our economy. The people whose history is being forgotten are the same ones who were 
told in school that Britain's success was based on how it manufactured and exported goods. They are now being told by heritage institutions and politicians that they should cherish Victorian industrial heritage and the Victorian values of hard work, self-reliance, and community. This is hypocritical, as many of their destroyed workplaces were constructed in the nineteenth century and the values are the very ones that the miners fought to protect. Within industrial communities, personal esteem and position are in large part based on a person's ability to work hard and do a good job. It has been rightly said that much of this disconnection is part of an on-going process that has its roots in the great population movements caused by the industrial revolution. A process that was necessary with making new traditions based on work (King and Timmins 2001). The difference, however, is the swiftness and the political ferocity with which British industry has been declined. This has been particularly difficult for those involved, because for many their lives and their homes still revolve around the industry they used to work in (Dennis et al. 1971). They live on estates where jobs are now scarce and walk past brick strewn fields where their places of work once stood. Their lives are dominated by their former jobs but also dominated by mourning a lost way of life. In the case of Woodlands many of the inhabitants were miners, and as far as they are concerned they still are (Turner 2000). Coming to terms with having a personal identy based on being a miner in a country where there are no deep mines is difficult enough but seeing their history ignored or rewritten makes this process more harrowing. These men and women know their place in history and in many cases that is all they have left. They know that the village in which they live and the industry in which they worked are as much a part of heritage as Buckingham Palace. These truths however are not being reflected in museums or displays of history and the buildings are also not being preserved or displayed. Instead the politics of heritage and identity building funnels resources into the ideology and heritage of elites, castles, monasteries, and stately homes.

\section{Conclusion}

The critique of heritage within this paper has been aimed at creating debate by highlighting a neglected section of history and questioning the direction in which the heritage sector is moving. Heritage has always followed the political agendas of governments and so this paper questions whether it is in the long term interest of heritage to blindly reinforce these agendas. Should not the wish to be inclusive of all class and genders, something that has dominated our theoretical studies for the last 30 years, now be included in the mainstream displays even if it involves questioning established views? In the 1960s and 1970s, academics in heritage came to the forefront as the voice of those disposed from history. This has diminished in the face of the neoliberal backlash and increased political interference. Politicians have called for the return of teaching history based on Kings and Queens and traditional heroes such as Nelson and Churchill, in order to rekindle pride in Britain. This is a call to use heritage for political reasons and would involve politician's judging which areas are more worthy of presentation. In this narrow portrayal of history there would be no place for seminal works such as The Making of the English Working Classes (Thompson 1963) with its critique of capitalism. It is important that our presentations and discussions include class, poverty, and their origins. These are not ways of life people choose, 
instead they are situations people are born or fall into. Despite this there are factors that profoundly influence your position within society and the value society places on your heritage. We should be aware of how the media campaigns of the last 40 years have affected the way we think of the poor and should take this into account in our work For despite what the tabloids and the media suggest, having a nice house and garden does not make you a good or moral person. Those in heritage should be more aware of these facts and be aware that television, radio and newspapers have very different agendas (Samuel 1999). So should we ask "is it really in the interest of heritage to tie its fortunes to a media industry in exchange for audience numbers?" Britain in the twenty-first century claims to be a society that aspires to equality opportunity for all. It is better educated, informed and far more diverse than it ever has been before, however conversely, it is a society deeply divided by class and wealth (Lipsy 2014). This contradiction is reflected in heritage in the amount of money and public exposure sections of history telling receive. To give equality of opportunity, be relevant and to be attractive to a now better educated and questioning population, the heritage industry needs to be inclusive of all sectors of society. If it fails in this task it will run the risk of becoming tainted as the ideological mouth piece of the state or a fun day out for the family. As Arendt (1951) explained, if you take what is good and call it our heritage and then bury what one dislikes and to believe it will disappear is folly, for it will resurface and undermine confidence in ideas of tradition (Arendt 1951). Her thoughts hold a continuing relevance, for if the failures of Britain's post war industries and Keynesian economics are remembered and their successes are ignored by heritage, then it is not heritage but propaganda.

Open Access This article is distributed under the terms of the Creative Commons Attribution 4.0 International License (http://creativecommons.org/licenses/by/4.0/), which permits unrestricted use, distribution, and reproduction in any medium, provided you give appropriate credit to the original author(s) and the source, provide a link to the Creative Commons license, and indicate if changes were made.

\section{References}

Arendt, H. (1951). The Burden of Our Time, Secker and Warberg, London.

Atkinson, H. (2012). The Festival of Britain: A Land and Its Ppeople, I. B. Taruis, London.

Babington, C., and Hughes, H., (1992). Conservation of the painted decoration at Brodsworth hall, English Heritage, Scientific and Technical Review, pp. 3-6.

Bailey, M., and Popple, S. (2011). The 1984/85 miners strike: re-claiming cultural heritage, in Smith, L. J., Shackle, P., and Campbell, G. (eds.), Heritage, Labour and the Working Classes, Routledge, London.

Baily, C. (2007). Black Diamonds: The Fall of an English Dynasty, London.

Balzer, M. (2013). The 1944 Education Act, Nordersted, Grinn.

Bayiles, C. (2004). History of the Yorkshire Miners 1881-1918, Routledge, London.

Beatty, C., Fothergill, S., Gore, T., (2012) The Real Level of Unemployment, 2012 Report, Centre for Regional Economic and Social Research, Sheffield Hallam University.

Big Pit. (2015). http://www.museumwales.ac.uk/bigpit/m, Accessed June 2015.

Binford, L. (1962). Archaeology as anthropology. American Antiquity 28:217-225.

Birmingham Museum. (2015). http://www.birminghammuseums.org.uk/bmag/highlights/birmingham-itspeople-its-history, Accessed June 2015.

Black, L. (2004). The impression of affluence: political culture in the 1950s and 1960s, in Black, L. and Pemberton, H. (eds.), An Affluent Society? Britain's Post War "Golden Age Revisited," Ashgate, Aldershot. 
Bogdanor, V., (2011). Britain in the twentieth Century: the Character of the Post-war Period, internet http:/www.gresham.ac.uk/lectures-and-events/britain-in-the-20th-century-the-character-of-the-post-warperiod, Accessed September 2014.

Brundage, A. (2001). The English Poor Law 1700-1930, Palgrave Macmillan, London.

Buchli, V., and Lucas, G. (2001). The archaeology of alienations: a late twentieth century council house, in Buchli, V. and Lucas, G. (eds.), Archaeologies of the Contemporary Past, Routledge, London.

Butler, D., (1999). The British General Election of 1951, Volume 3 of British General Elections 1945-92, Macmillan, London.

Chambers, E., (2006). Heritage Matters: Heritage, Culture, History and Chesapeake Bay, University of Maryland. Maryland, College Park, MD.

Chapman, J. (2015). Swashbucklers: The Costume Adventure Series, Manchester University Press, Manchester.

Claughton, P., (2009). Quantity or quality: the presentation of mining history in England and Wales, in Linton, D. (ed.), The Lode of History Proceedings of the Welsh Mines Society Conference 2007, Welsh Mines Society. Llanaber.

Coal Industry Social Welfare Organisation, (CISWO). (2014). Miners Welfares, http://www.ciswo-services. org.uk/swamp/minerswelfares. Accessed September 2014.

Comfort, N. (2012). The Slow Death of British Industry: A Sixty Year Suicide, Bite Back, London.

Constantine, A., and Allfrey, M., (1999). Brodsworth Hall, in Chitty, G. and Backer, D. (eds.), Managing Historic Sites and Buildings: Reconciling Presentation and Preservation, Routledge, Abingdon,

Contemp-hist-arch list. (2011). Contemp-hist-arch@jiscmail.ac.u. Accessed August 2011.

Council for British Archaeology. (2014). Dan Snow Becomes CBA President, http://new.archaeologyuk. org/dan-snow-becomes-cba-president. Accessed August 2014.

Cox, E. (2011). On the wrong track; An analysis of the autumn statement on transport infrastructure Institute for Public Policy Research, http://www.ippr.org/files/images/media/files/publication/2011/12/wrongtrack_dec2011\%201_8411.pdf?noredirect=1, Accessed January 2016.

Davies, C. (2014). Benefits street is an excuse for viewers to judge and sneer says Claire short. Guardian Media Group 4(2).

Dennis, N., Henriques, F., and Slaughter, C. (1971). Coal is Our life, Tavistock, London.

Department for Business Innovation and Skills (2010). Department for Business Innovation and Skills Economic Paper No. $10 B$ Manufacturing in the UK Supplementary Analysis, December 2010, Department for Business Innovation and Skills, London.

Department of Energy. (2014). Coal statistics Gov.Uk, https://www.gov.uk/govermentcollecteionscoalstatistics. Accessed September 2014.

Dodd, K., and Dodd, P., (1992). From the east end to EastEnders: representations of the Working Class, 18901990, in Strinati, D. and Wagg, S. (eds.), Come On Down? Popular Media Culture in Post-War Britain, Routledge, London, pp. 32-116.

Domingo, S. (2014). The Impact of Austerity Measures on People and Local Government, Author House, London.

Doncaster Metropolitan Borough Council. (2014). Conservation areas in Doncaster, Internet, http://www. doncaster.gov.uk/services/planning/woodlands-conservation-area, Accessed August 2014.

Donnelly, M., (2000). Sixties Britain: Culture, Society, and Politics, Routledge, London.

Douglas, A., (2014). MPs to vote on whether thatcher government misled country over miner's strike, The Northern Echo, http://www.thenorthernecho.co.uk/news11549519.MPs to vote_on_whether_Thatcher Goverment_Misled_country_over_Miners_39_Strike. Accessed October 2014.

Douglass, D. (2010). Ghost Dancers, $\bar{C}$ Christie, London.

Dresser, M., and Hann, A. (2013). Slavery and the British Country House, English Heritage, Swindon.

Elliot, B. (2004). Yorkshires Flying Pickets in the 1984-85 Miners Strike, Wharncliffe, Barnsley.

English Heritage. (2014). Peoples views, https://www.historicengland.org.uk/advice/heritage-atrisk/industrial-heritage/how-are-weclassyfying/industrial/peoples-views/. Accessed. July 2014.

Evans, E. (2013). Thatcher and Thatcherism: The Making of the Contemporary World, Routledge, London.

Fordham, D. (2009). Brodsworth Colliery, Woodlands and Highfields: Early Development, Fedj El Adourn, Doncaster.

Forestry Commission. (2014). Brodsworth community woodland, http://www.forestry.gov. uk/forestry/EnglandSouthYorkshireNoForestBrodsworthCommunityWoodland, Accessed August 2014.

Gardener, M., (2008). Titanic quarter creating a new heritage place, in May, S., Orange, H., and Penros, S. (eds.), The Good, the Bad and the Unbuilt: Handling the Heritage of the Recent Past. Archaeopress, London, pp. 29-40.

Gilchrist, R. (1999). Gender and Archaeology: Contesting the Past, Routledge, New York. 
Gordon, A. (2008). Ghostly Matters: Haunting and the Sociological Imagination, University of Minnesota Press, Minneapolis.

Gove, M., (2015). Public school domination morally indefensible, The Guardian, http://www.theguardian.com education, Accessed July 2015.

Hadjimatheou G., and Sarantis N., (1998). Is UK deindustrialization inevitable? Britain's Economic Performance, Routledge, London.

Hamilakis, Y. (2007). Archaeology as capitalism, in Hamilaks, Y. and Duke, P. (eds.), Archaeology and Capitalism from Ethics to Politics, West Coast Press, Walnut Creek, CA.

Hamilton-Paterson, J. (2011). Empire of the Clouds: When Britain's Aircraft Ruled the World, Faber and Faber, London.

Harris, J. (2004). Britpop, Cool Britannia, and the Spectacular Demise of English Rock, Da Capo Press, Cambridge.

Harris, G., (2014). A new era of local authority funding? Museums Journal, 114(10):6.

Hennessy, P., and Ahmed, K. (2014). David Cameron campaigns to put the great back in Britain. The Telegraph. September 17.

Hewison, R. (2007). The Heritage Industry: Britain in a Climate of Decline, Methuen, York.

Hickman, T. (2008). Called Up Sent Down: The Bevin Boys' War, History Press, Stroud.

Hobsbawn, E., and Ranger, T. (1988). Inventing Tradition, Cambridge University Press, Cambridge.

Hodder, I. (2012). Entangled: An Archaeology of Relationships Between Humans and Things, WileyBlackwell, Chichester.

Hothi, N. (2005). Globalisation and Manufacturing Decline: Aspects of British Industry, Blackwell, Oxford. Howard, E. (1900). Garden Cities of Tomorrow, Swan and Sonnenchine, London.

Jargo, M. (2015). Clement Attlee: The Inevitable Prime Minister, Bite Back, London.

Jenkins, S. (2007). Thatcher and Sons: A Revolution in Three Acts, Penguin, London.

Jones, O. (2011). Chavs: The Demonization of the Working Class, Verso, London.

Jorvik Viking Centre. (2015). http://www.jorvik-viking-centre.co.uk, Accessed June 2015.

Kavanagh, D., and Morris, P. (1989). Consensus Politics From Attlee to Thatcher, Wiley-Blackwell, Oxford.

Kendall, G., (2012). English Heritage reduces hours, Museums Journal, 111(4): 6.

Kendall, G., (2016). Museums across the UK face closure threat https://www.museumsassociation. org/museums-journal/news06072016-axe-to-museum-services, Accessed July 2016.

Keynes, J., (1936). The General Theory of Employment, Interest, and Money. Macmillan, London.

Kiddey, R., and Schofield, J., (2011). Embrace the margins: adventures in archaeology and homelessness. Public Archaeology, 10: 4-22.

King, S., and Timmins, G. (2001). Making Sense of the Industrial Revolution: English Economy and Society 1700-1850, Manchester University Press, Manchester.

Kynaston, D. (2007). Austerity Britain, 1945-1951, Bloomsbury, London.

Kynaston, D. (2013). Modernity in Britain: Opening the Box, 1957-1959, Bloomsbury, London.

Laslett, P. (1965). The World We Have Lost: England Before the Industrial Age, Charles Scribner's Sons, New York.

Latham, D., (1994). Archaeology field and research unit http://www.sytimescapres.org.uk/files/u1 /doc/rotherham-exstractive/pdf

Lawler, S. (2000). Escape and escapism: representing working-class women. In Munt, S. (ed.), Cultural Studies and the Working Class, Cassell, London, pp. 113-128.

Layton, R. (ed.) (1994). Conflict in the Archaeology of Living Traditions, Routledge, London.

Lipsy, D., (2014). The Meretriciousness of meritocracy, in Political Quarterly, 85:37-42.

Little, B., and Shackle, P. (2014). Archaeology, Heritage and Civic Engagement: Working Toward the Public Good, Left Coast Press, Walnut Creek, CA.

Local Government Ombudsman. (2013). No Place Like Home, councils use of unsuitable bed and breakfast accommodation for homeless families and young people, internet, http:/www.lgo.org.uk. downloads/special\%20 reports/, Accessed August 2014.

Ludlow Collective (2001). Archaeology of the Colorado Coal Field War, 1913-1914, in Buchli, V., and Lucas, G. (eds.), Archaeologies of the Contemporary Past. Routledge, London, pp. 94-107.

MacGregor, I. (1987). The Enemies Within, Fontana, Glasgow.

Mail Online. (2014). Stop criticising me, News online http://www.dailymail.co.uk/news/article-2667336 /Father-13-lives-new-supersize-council-house-collecting-53k-benefits-year-threatens-increase-familyspite-critics.html, Accessed September 2014

Marshall, Y., (2009). Archaeologies of resistance, in Terendy, S., Lyons, N., and Janse-Smekal, M. (eds.), Que(e)rying Archaeology, Chacmool Archaeological Association, Calgary, pp.12-20.

Massey, D., (2005). For Space, Sage, London. 
McDowell, L. (2003). Redundant Masculinities? Employment Change and White Working Class Youth, Blackwell, Oxford.

McKittrick, D., and McVea, D. (2000). Making Sense of the Troubles, Blackstaff, Chicago.

Millar, S., and Walker, M. (1984). A State of Siege: Politics and Policing of the Coalfields: Miners' Strike, Canary, Sheffield.

Milne, S. (2004). The Enemy Within: Thatcher's Secret War Against the Miners, Verso, London.

Moffat, H. (2005). Brodsworth Hall Information Pack for Teachers, English Heritage, Colchester.

Mullins, P. (2007). Ideology power and capitalism in historical archaeology of consumption, in Meskell, L. and Preucel, R. (eds.), Companion to Social Archaeology, Blackwell, Oxford, pp.180-194.

Murie, A., (1997). The social rented sector, housing and the welfare state in the UK, Housing Studies, 124,37461.

National Coal Mining Museum for England. (2014). http:/www.ncm.org.uk/whats-on/exhibitions/currentexhibition, Accessed August 2014.

National Coal Mining Museum for Scotland. (2015) http://nationalminingmuseum.com. Accessed June 2015.

Office for National Statistics. (2014b). A Century of Home Ownership and Renting in England and Wales, internet http:/www.ons.gov.uk/ons/rel/census/2011-census-analysis/a-century-of-home-ownership-andrenting-in-england-and-wales.hmtl, Accessed August 2014.

Office for National Statistic's. (2014a). 170 years of Industry, internet, http://www.ons.gov. uk/ons/rel/census/2011-census-analysis/170-years-of-industry/index.html, Accessed September 2014.

Palmer, M., and Neverson, P. (1998). Industrial Archaeology: Principles and Practice, Routledge, London.

Peoples History Museum. (2015). http://www.phm.org.uk/about-us/history/, Accessed June 2015.

Pine, B., and Gilmore, J., (1998). Welcome to the experience economy, Harvard Business Review, JulyAugust: 97-104.

Rennie, P. (2007). Festival of Britain: Design 1951, Antique Collectors' Club Woodbridge, England.

Roberts, A. (2010). Past, Present, and Future, British Academy, London.

Rowntree, B., and Bradshaw, J. (2000). Poverty: A Study of Town Life, Policy, York.

Rowthorn, R., and Coutts, K., (2013). De-industrialization and the balance of payments in advanced economies, Centre for Business Research University of Cambridge. Cambridge, England.

Samuel, R., (1986). The Enemy Within, Pit Villages and the Miners' Strike of 1984-5, in Samuel, R., Bloomfield, B., and Boanas, G. (eds.), Routledge and Kegan Paul, London.

Samuel, R. (1999). Island Stories: Unravelling Britain Theatres of Memory, Vol. II, Verso, London.

Samuel, R. (2012). Theatres of Memory: Past and Present in Contemporary Culture, Verso, London.

Sandbrook, D. (2009). White Heat: A History of Britain in the Swinging Sixties, 1964-1970, Abcus, London.

Sayer, R. (2005). The Moral Significance of Class, Cambridge University Press, Cambridge.

Schofield, J. (2005). Combat Archaeology, Material Culture and Modern Conflict, Duckworth, London.

Seldon, A., and Collings, D., (2013). Seminar Studies in History: Britain Under Thatcher, Routledge Abingdon, England

Shanks, M. (1996). Classical Archaeology of Greece: Experiences of the Discipline, Routledge, London.

Shaw, K. (2012). Mining the Meaning: Cultural Representations of the 1984-85 UK Miner's Strike, Cambridge Scholars Publishing, Newcastle upon Tyne, England.

Simey, T. (1980). Charles Booth, Social Scientist, Greenwood, London.

Smith, M., (1998). Democracy in a Depression: Britain in the 1920s and 1930s, University of Wales Press, Cardiff.

Smith, L. (2006). Uses of Heritage, Routledge, London.

Smith, L. (2008). Heritage, gender and identity, in Graham, B. and Howard, P. (eds.), The Ashgate Research Companion to Heritage and Identity, Ashgate, Farnham, pp. 159-178.

Smith, L., (2011). Class still matters, in Smith, L., Shackel, P., and Campbell, G. (eds.), Heritage, Labour and the Working Classes, Routledge, Abingdon.

South Yorkshire Historic Environment Characterisation Project. (2006) http://sytimescapes.org. uk/zones/barnsley/B17, Accessed June 2015.

Stanley, T., (2011). Conservative nostalgia for Victorian era is dangerous, in The Guardian.com, Internet, www.TheGuardian.com/commentisfree, Accessed August 2014.

Steel, P., (2014). Government confirms English Heritage restructure, In Museums Association, http:/www. museumsassociation.org/musumsjournal, Accessed October 2014.

Stratton, M., and Trinder, B. (2000). Twentieth Century Industrial Archaeology, Taylor and Francis, London.

Tervor-Roper, H. (1988). The invention of tradition: the highland tradition of Scotland, in Hosbawn, E, and Ranger, T. (eds.), Inventing Tradition, Cambridge University Press, Cambridge.

Thatcher, M., (1977). The new renaissance, Speech to Zurich Economic Society, Margret Thatcher Foundation, http://www.margretthatcher.org/speaches, Accessed September 2014.

Thatcher, M. (1993). Margret Thatcher the Downing Street Years, Harper, London. 
The Guardian. (2014). The poverty map of England, http://www.thegaurdian.com/news/datalog/2012, Accessed August 2014.

The Telegraph. (2013). Former miners celebrate death of Thatcher, http://www.telegraph.co. uk/news/politics/margaret-thatcher/10001016/Former-miners-turn-ut-to-celebrate-the-death-of-MargaretThatcher, Accessed August 2014.

The Telegraph. (2015). Calls for Hillsborough style inquiry into police handling of 1984 miners' strike. www. telegraph.co.uk./news/uknews, Accessed June 2015.

Thomas, S., and Lea, J., (2014). Making archaeological heritage accessible in Great Britain: enter community archaeology, in Thomas, S. and Lea, J. (eds.), Public Participation in Archaeology, Boydell Press. Woodbridge, pp. 23-34.

Thompson, E., (1963). The Making of the English Working Class, Victor Gollancz, London.

Thompson, E., (1966). History from below, Times Literary Supplement, April7, pp. 279-80.

Thorpe, A. (1992). Britain in the 1930s: A Deceptive Decade, Wiley-Blackwell, London.

Thurley, S., (2009). From boom to bust: the politics of heritage 1997 to 2009, http://www.gresham.ac. uk/lectures-and-events/from-boom-to-bust-the-politics-of-heritage-1997-to-2009, Accessed June 2015.

Thurley, S. (2013). Men From the Ministry: How Britain Saved Its Heritage, Yale University Press, London.

Timmins, N. (2001). The Five Giants: A Biography of the Welfare State, Harper Collins, London.

Timmins, C., and Stuart-Smith, J. (2001). Cockney on Our Screens: A Phonetic Analysis of a Cockney Character Accent, Language, the Media and International Communication, University of Oxford, Oxford.

Townsend, M., (2014). Police accused of foot dragging over miners' strike inquiry, in, The Guardian, internet, http://www.thegauardian.com/uk-news/2014/jun/15, Accessed August 2014.

Turner, R. (2000). Coal Was Our Life: An Essay on Life in a Yorkshire Pit Town, Perpetuity, Leicester.

Turner, A. (2013). Crisis? What Crisis: Britain in the 1970's, Aurum, London.

UK Coal. (2014). UK Coal secures funding for managed closure of deep mines, http://www.ukcoal.com/latest news, Accessed August 2014.

United Kingdom Government. (2012). Special feature articles-coal in 2012, https://www.gov.uk/goverment/data, Accessed, October 2014.

Vinen, R. (2009). Thatcher's Britain: the Politics and Social Upheaval of the Thatcher Era, Pocket, London.

Walker, R., (2001). How to abolish public housing: implications and lessons from public management reform, Housing Studies, 16:675-696.

Wentworth Woodhouse. (2016) http://www.wentworthwoodhouse.co.uk , Accessed January 2016.

Wheeler, M., (1974). Sir Mortimer and Magnus, BBC 24th October 1974, http://bbc.co.uk/programes, Accessed July 2014.

Williams, C., (2007). The Angry Years: The Rise and Fall of the Angry Young Men, Robson, London.

Winterton, J., and Winterton, R. (1989). Coal, Crisis and Conflict, Manchester University Press, Manchester.

Wylie, A., (2004). Why standpoint matters, in Harding, S. (ed.), The Feminist Standpoint: A Reader, Routledge. London, pp. 339-352.

York Castle Museum. (2014). The sixties, http://thesixties.org.uk/welcome, Accessed August 2014. 